\title{
The Game Changer China Pakistan Economic Corridor (CPEC): A SWOT Analysis
}

\author{
Ghulam Muhammad Kundi \\ Gomal University, DI Khan, Pakistan
}

\begin{abstract}
China Pakistan Economic Corridor (CPEC) is dreamed to be the game changer not only for China and Pakistan but other 50 regional, Middle East, Central Asian Republics, and European countries too. It is one of its kind a huge project with billion US\$ investment by China. Since its inception, the internal controversies and disputes in Pakistan on the sharing of benefits as well as interests and concerns of the regional and international players are posing threats to it. The review article aims to investigate and analyze the strengths and weakness and opportunities and threats (SWOT) for CPEC. To analyze the qualitative data, a computer based software program ATLAS.ti was used by employing multiple methods like discourse, hermeneutics, and heuristic by Moustakas. The schematic model of the theoretical framework elaborates the association and impact between and on the dependent, independent, and mediating variables of the study. It was found that if the security, political support, internal and external threats, coordination and cooperation and involvement of stakeholders are properly addressed, the CPEC will bear the fruits.
\end{abstract}

Keywords: CPEC, security, political support, internal and external threats, coordination and cooperation, involvement of stakeholders

\section{Introduction}

\section{Background and Rational}

The prosperity and socio-economic uplift of any country depends on the development of the required infrastructure that plays an instrumental role in realizing their dreams. CPEC or the China Pakistan Economic Corridor is one of the multifaceted projects of its kind, which has been envisioned in connection with strategic partnership between the two governments, i.e., Pakistan and the China (Aymen, 2016).

The China Pakistan Economic Corridor has been initiated under the concept of "One Belt, One Road" (OBOR) and the vision of this CPEC was presented by Chinese President Xi Jinping to link the trade through land and maritime among more than 60 countries of Asia and Europe (Irshad, Qi, \& Arshad, 2015). And this OBOR vision, of which CPEC is a part, will contribute to the regional and global growth by ensuring the development of infrastructure and to physically integrate more than 60 economies around the globe (Rizvi, 2014-2015). However, CPEC was formally announced in July 2013 during the Pakistan prime minister's visit to China. The China Pakistan Economic Corridor (CPEC) is one of the long term strategic plan and expected to complete from 2014-2030 with total investment about $\$ 46$ billion by China (Akhter, 2016). Fifty-two of the countries have shown their interest to participate in the CPEC (Nawaz Sharif, 2017)

Ghulam Muhammad Kundi, Ph.D., Professor, Department of Public Administrationm, Gomal University. 
Pakistan is located in southern Asia bordered with Afghanistan, Iran, India, China, and Arabian Sea and it is enjoying an exceptional geographical landscape that varies from deserts, high mountains, forests to green belts, and its terrain consists of flat Indus plain in east inter alia the mountains in the north and northwest and further the Baluchistan plateau in the west (Dawn News, 2016). The north Pakistan also has a few of the world's highest peaks, i.e., K2 (28,250 ft.) and Nanga Parbat (26,660 ft.). Likewise, Pakistan's economy is the 26th largest in the world with regard to Purchasing Power Parity (PPP), while according to IMF (International Monetary Fund), Pakistan's GDP for the FY15 was $\$ 271$ billion, and its value is thus equal to $0.39 \%$ of the world economy. Moreover, the per capita GDP was also \$1,427 (Trading Economies, 2016). Furthermore, the World Bank reports that Pakistan's GDP is growing at rate of is $4.7 \%$.

Economists and strategic analysts believed that CPEC is a game changer project not only for the Pakistan and China but for the whole region in specific and for the world in general (Ali, 2016). Ritzinger (2015) was of the view that this will be an edge to China's economy and will increase its export and transit capacity manifolds; further, other companies will also use it to export goods and services to China due to short route and less cost of shipping and the transit time, for example, the land locked central Asian countries, i.e., Afghanistan, Kyrgyzstan, Kazakhstan, Tajikistan, Turkmenistan, Uzbekistan, etc., as Gwadar seaport is at the distance of 2,500 km in comparison to Iran $(4,500 \mathrm{~km})$ and Turkey $(5,000 \mathrm{~km})$. Thus it is expected that this route will not only be used by China but also European countries, Middle Eastern countries will also took benefits to gallop on the road of development and prosperity (Aymen, 2016).

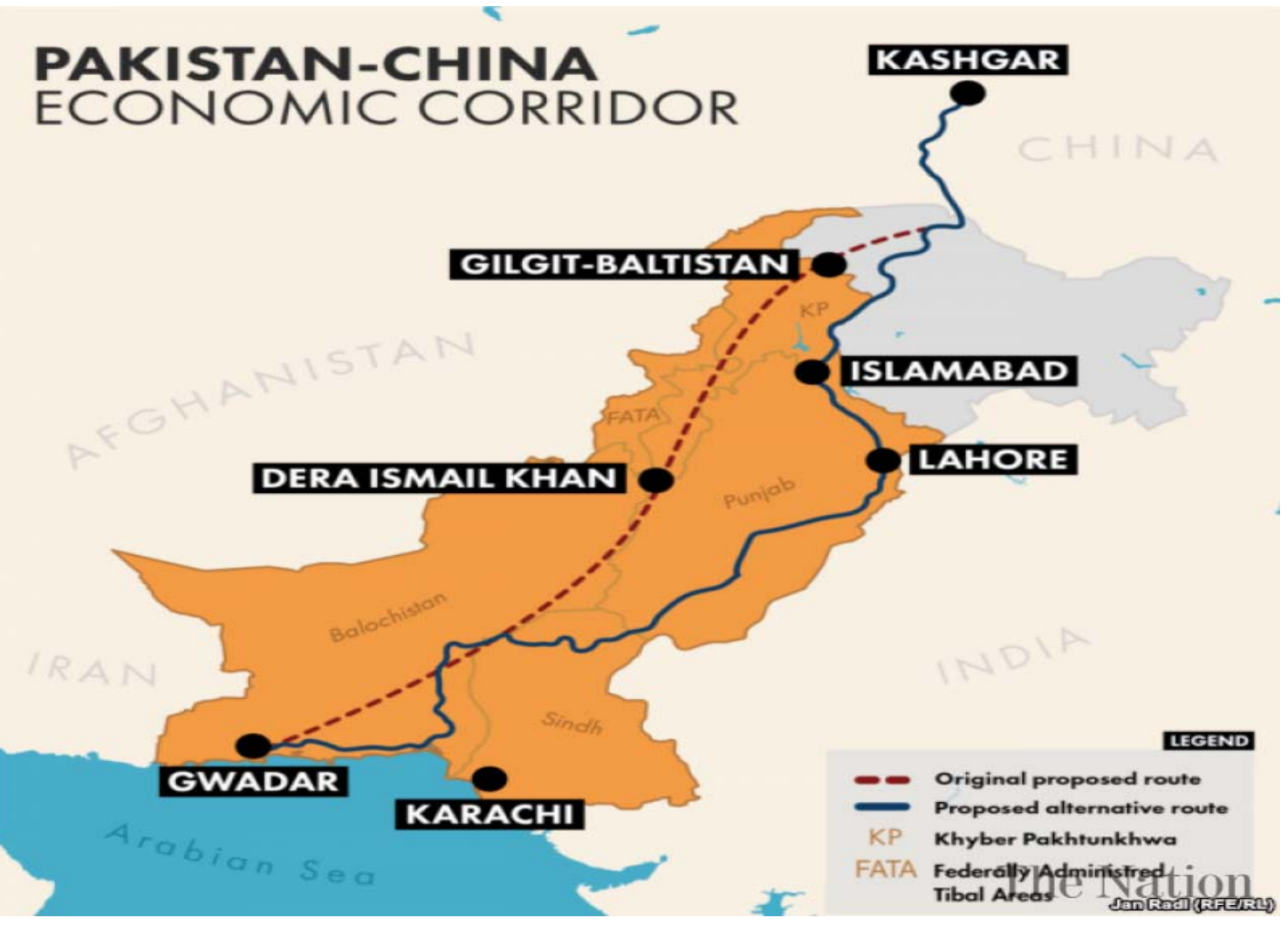

Figure 1. Route map. 


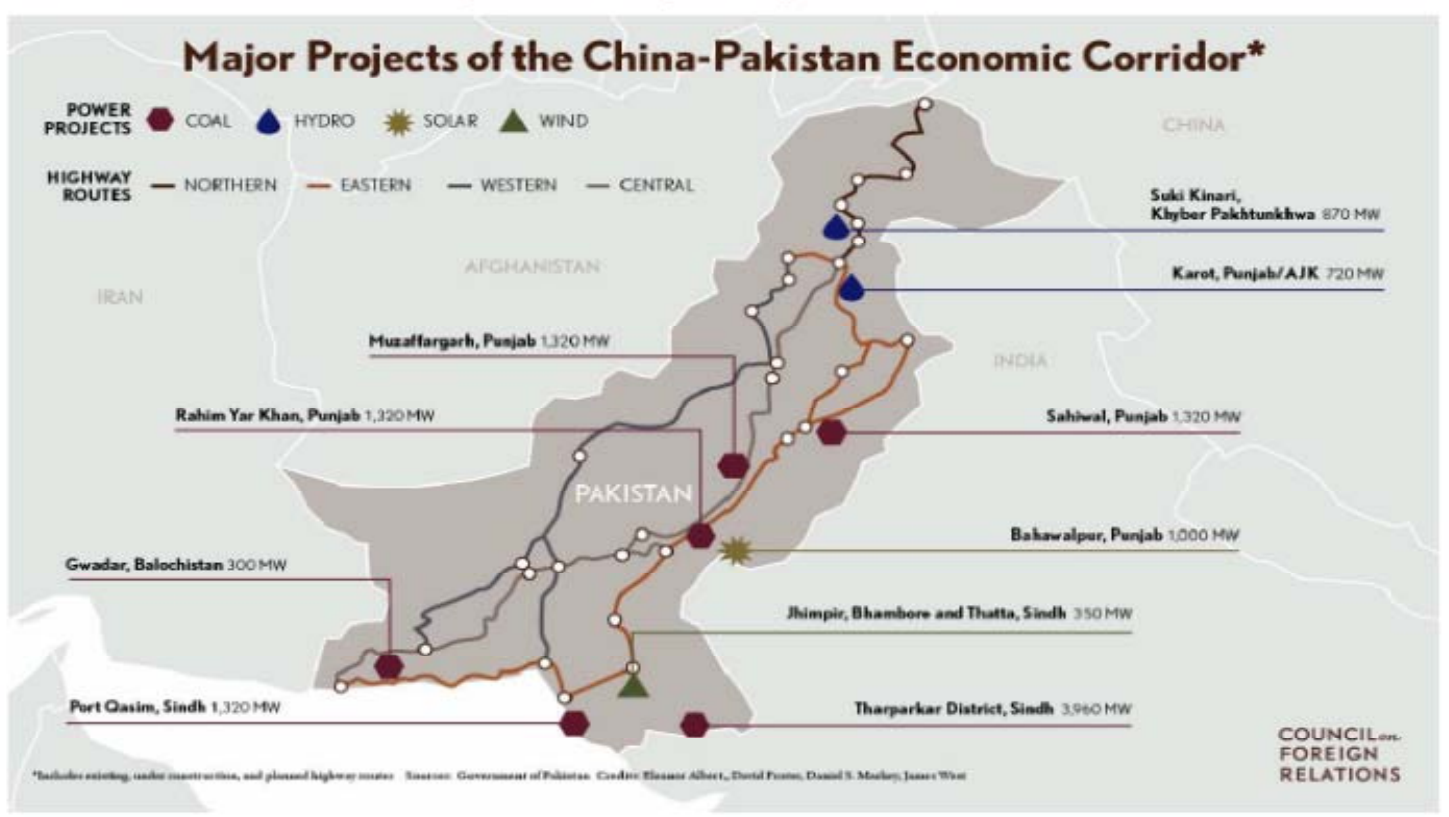

Source: Daniel S. Markey, "Behind China's Gambit in Pakistan," Expert Brief, Council on Foreign Relations, 2016. http://www. cfr.org/pakistan/behind-chinas-gambit-paktstan/p37855.

Figure 2. Major projects of CPEC.

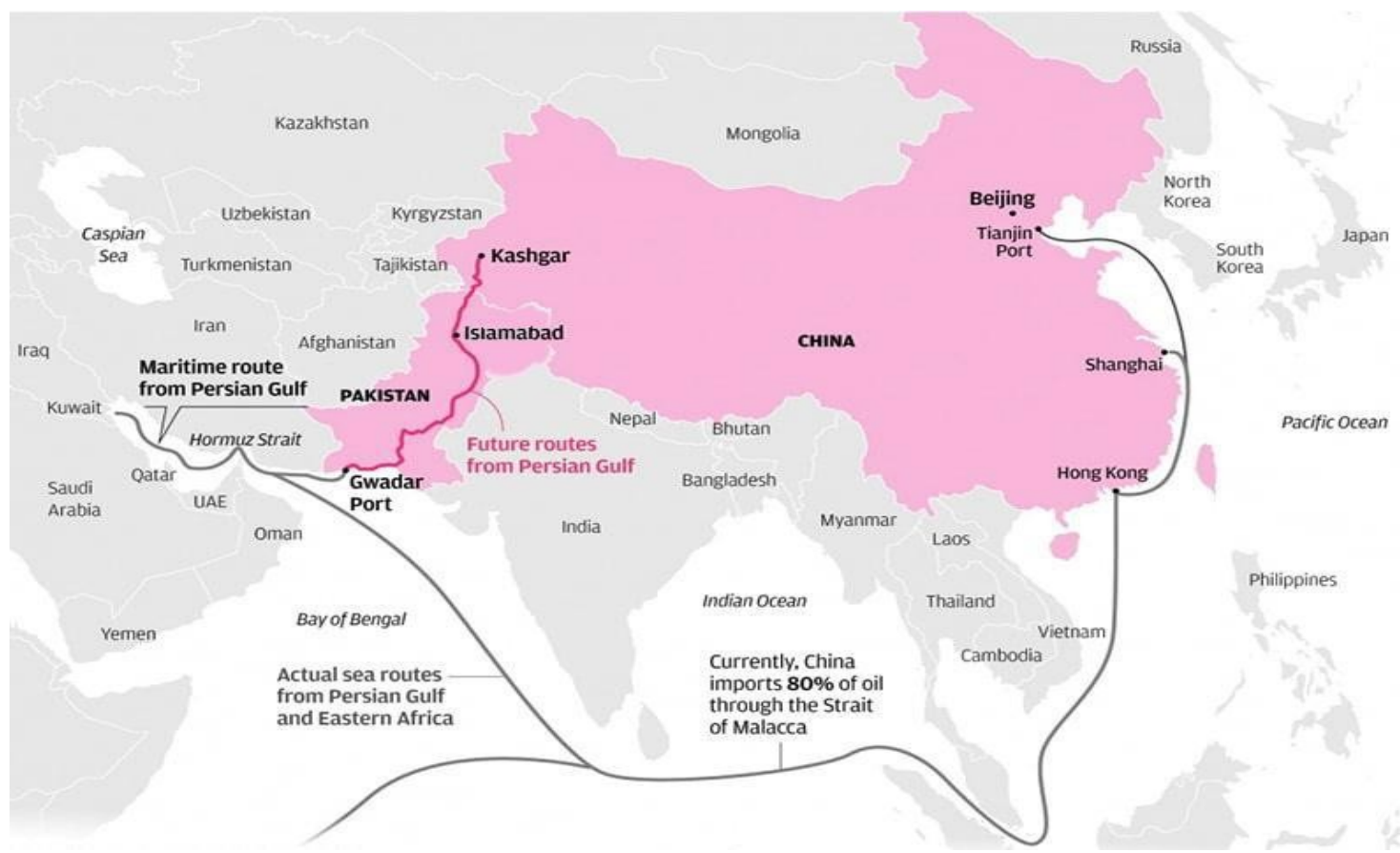

Figure 3. Perspective on the CPEC and the current routes. 


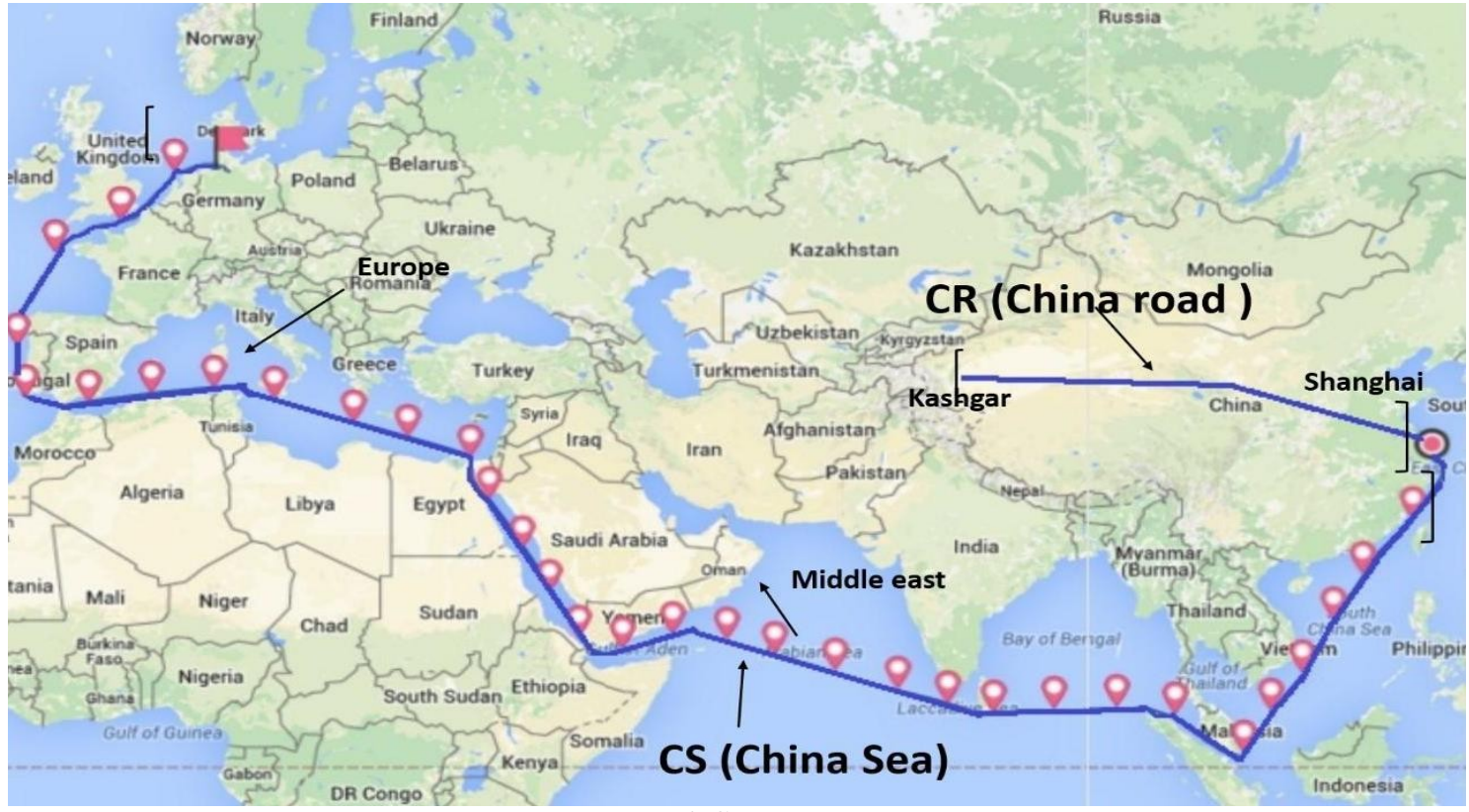

Figure 4. Current route.

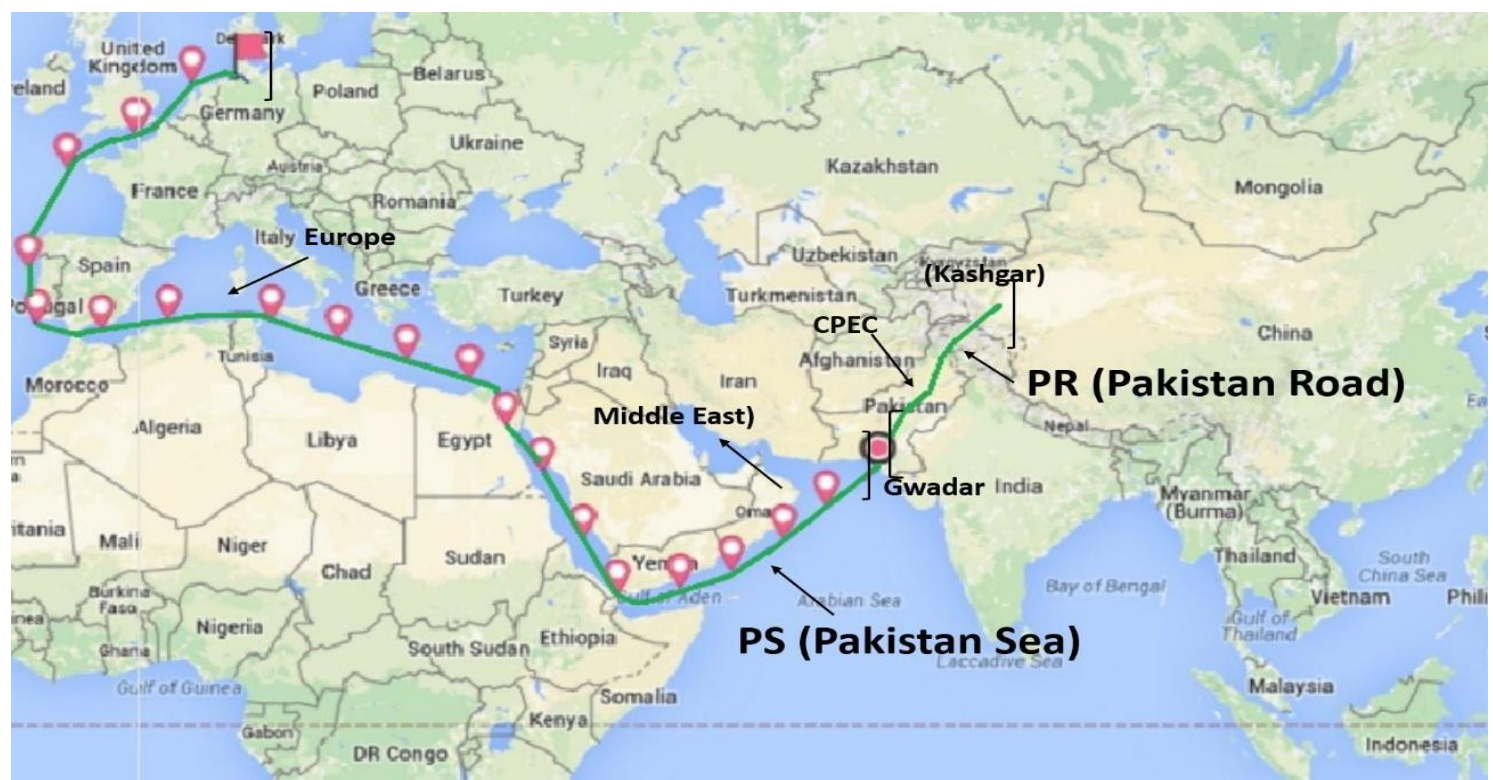

Figure 5. Proposed route. 


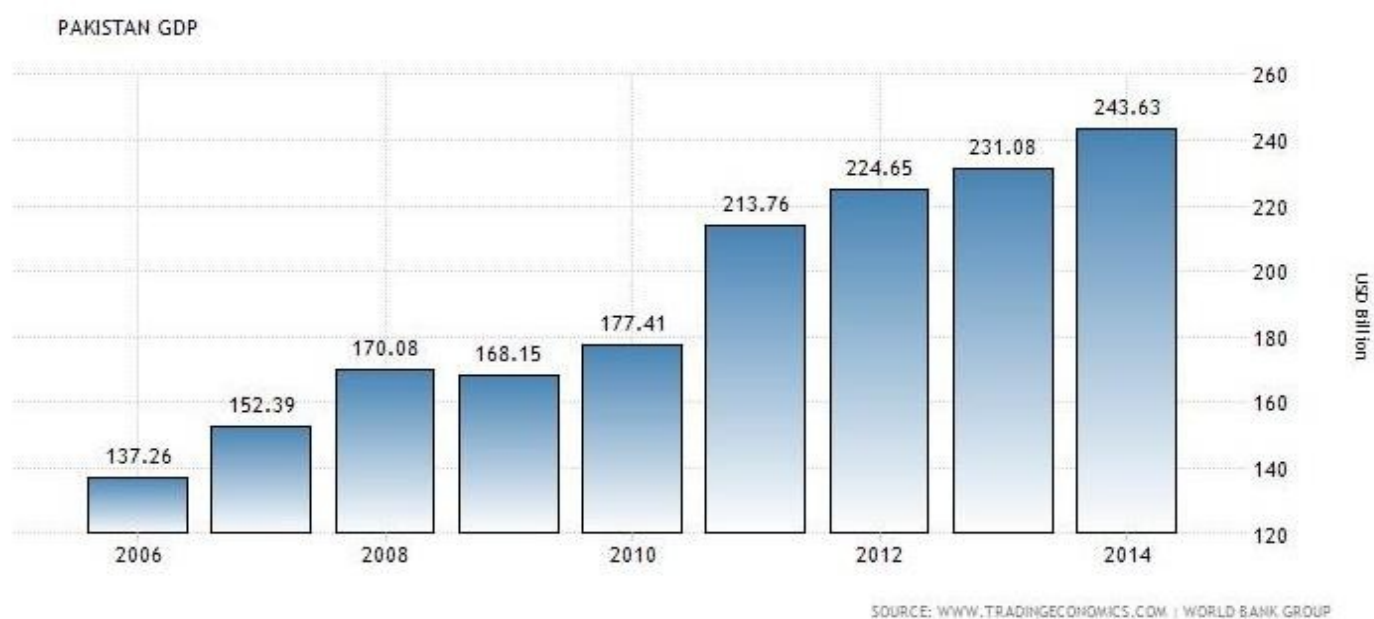

Figure 6. GDP rate between the years 2006 to 2014.

Table 1

Comparison of Distance Between Current and Proposed Route of CPEC

\begin{tabular}{lllll}
\hline Origin port & Destination port & Current route distance & CPEC route distance & Difference in KM \\
\hline \multirow{3}{*}{ Kashgar } & Hamburg & 25,114 & 14,627 & 10,487 \\
China & Le Havre & 24,266 & 13,779 & 10,487 \\
& Rotterdam & 24,645 & 14,158 & 10,487 \\
& Jeddah & 17,298 & 6,811 & 10,487 \\
& Kuwait & 16,380 & 4,813 & 11,567 \\
& Oman & 15,133 & 3,665 & 11,468 \\
\hline
\end{tabular}

Table 2

Comparison of Shipping Cost Between Current and CPEC Route

\begin{tabular}{lllll}
\hline Ports & Exports & Imports & Total trading volume & $10 \%$ save \\
\hline Germany & $\$ 92.50$ & $\$ 87.40$ & $\$ 179.90$ & $\$ 17.99$ \\
France & $\$ 50.40$ & $\$ 20.00$ & $\$ 70.40$ & $\$ 7.04$ \\
Netherland & $\$ 44.70$ & $\$ 10.30$ & $\$ 55.00$ & $\$ 5.50$ \\
Saudi Arabia & $\$ 19.80$ & $\$ 48.00$ & $\$ 67.80$ & $\$ 6.78$ \\
Kuwait & $\$ 3.85$ & $\$ 8.93$ & $\$ 12.78$ & $\$ 1.278$ \\
Oman & $\$ 1.21$ & $\$ 18.90$ & $\$ 20.11$ & $\$ 2.011$ \\
Total & $\$ 212.46$ & $\$ 193.53$ & $\$ 405.99$ & $\$ 40.599$ \\
\hline
\end{tabular}

Table 3 presents savings by supply chain, i.e., $\$ 41$ billion dollars per year.

Table 3

Comparison of Transit Time Between the Current and CPEC Route Overall Impact of CPEC (in Billions)

\begin{tabular}{lllll}
\hline Origin port & Destination port & Current shipping cost & CPEC route shipping cost & Difference \\
\hline \multirow{3}{*}{ Kashgar } & Hamburg & $\$ 3900-\& 4100$ & $\$ 2500-\& 2700$ & $\$ 1400$ \\
China & Le Havre & $\$ 3900-\& 4100$ & $\$ 2500-\& 2700$ & $\$ 1400$ \\
& Rotterdam & $\$ 3900-\& 4100$ & $\$ 2500-\& 2700$ & $\$ 1400$ \\
& Jeddah & $\$ 3300-\& 3600$ & $\$ 1600-\& 1800$ & $\$ 1700-\$ 1800$ \\
& Kuwait & $\$ 3300-\& 3600$ & $\$ 1600-\& 1800$ & $\$ 1700-\$ 1800$ \\
& Oman & $\$ 3200-\& 3400$ & $\$ 1000-\& 1200$ & $\$ 2200$ \\
\hline
\end{tabular}




\section{Review of the Existing Literature}

The CPEC is a multidimensional project where organism's amalgamation plays a significant role, and it will provide Pakistan with an exceptional breakthrough to lead and elevate new technologies and to enhance the managerial practices which is expected to catch broader use in the country. However, the success in realizing this goal, on other hand depends on if Pakistan will be able to ripen out-and-out institutions that will be a position to integrate and transfer this amassed experience. With an inclusive setup of roads and highways, the CPEC would substantially develop connectivity and growth of provinces (Hussain, 2016).

The CPEC if implemented faithfully would change the face of Baluchistan and in the future, Pakistan would be its ultimate beneficiary. The central focus of CPEC is to establish and develop the Gwadar, and this deep seaport was formally leased to China in 2016 for 43 years, i.e., 2059. Now Gwadar seaport is fully operational, whereas a new airport is near to the completion. The major focus is being paid on to improve the infrastructure, which is expected to attract both local and foreign investment (Simrit, 2016).

The significance of the CPEC for China, and particularly for Pakistan, however, cannot be flamboyant as it will resuscitate the primordial Silk Road (Shah, 2017). CPEC will fortify and add a lively economic strength to the strategic partnership between Pakistan and China (Hussain, 2016). It will provide a shortest and safe route for China to trade with rest of the world through an interaction with Pakistan. Initially, China is targeting about $80 \%$ of trade, i.e., $\$ 4,000$ billion through this route that will further help China to develop its vast western region and accelerate the investment, trade, and growth in Pakistan, too (Amna, 2016).

Figure 7 shows the trade connectivity through CPEC.

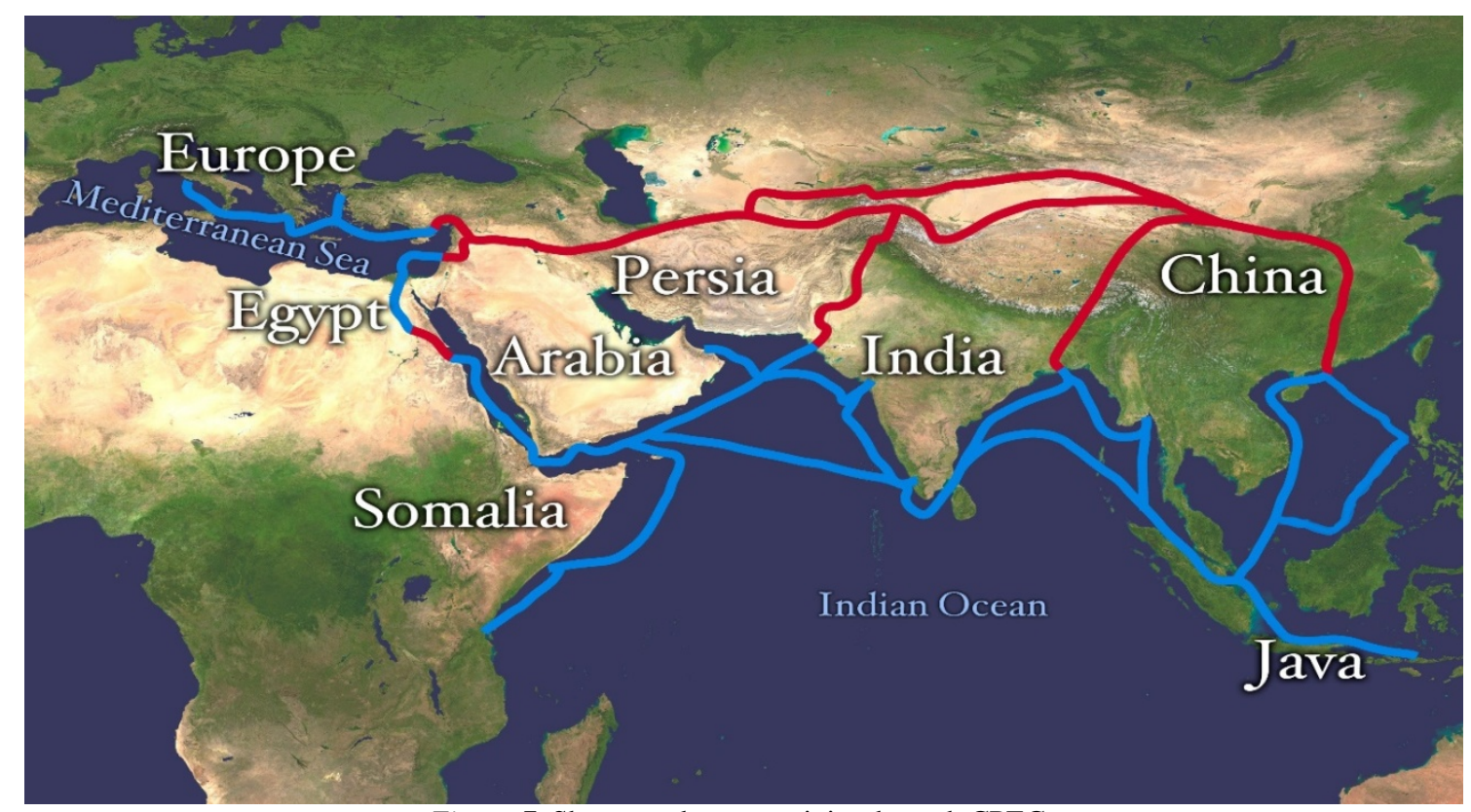

Figure 7. Shows trade connectivity through CPEC.

\section{SWOT Analysis of CPEC}

The SWOT analysis of the CPEC is based on the critical examination and analysis is given below:

Strengths. The CPEC project will support and strengthen both countries in numerous sectors especially in terms of trade, business, infrastructure, energy, transport, as well as social sectors. China will make \$3.5 billion 
investment to establish railways network from Peshawar to Karachi and it will connect almost all major and small cities of the Sindh, Baluchistan, and Khyber Pakhtunkhwa provinces. Similarly, the project of CPEC will provide new avenues for investment in business and trade in the areas of minerals, energy, power, communication, and other regional development programs (Griffin, 2015). Likewise, it will help to extend the Eurasian Continental Land Bridge, Lianyungang-Rotterdam (Kashgar offshoot) by connecting the Central States of Former USSR (Union of Soviet Socialist Republics) to the Peshawar in Khyber Pakhtunkhwa province (Amna, 2016). This extension will offer ample opportunities and benefits to China and Pakistan because of the shortest route, i.e., from Karachi to Peshawar.

Weakness. The CPEC is a multi-billion US\$ project; due to rapid global, regional, and local changing conditions, it will be impossible to reap its fruits in perfectly even using all possible means and resources as according to the project of CPEC, several long routes of roads are in the process of construction, where varying political interests are perceived to create problems both countries not only for government but also for the common citizens and business communities, too (Sial, 2014). Furthermore, this giant project needs to hire massive manpower yet, and the lack of seriousness on part of any part could deter its implementation (Ahmar, 2015).

Additionally, lack of transparency allocation, distribution, and utilization of funds may worsen and shake the confidence and trust of the investors. Finally, the formulation, execution, and modification of the internal and external policies of the project have lack in terms of its frequent interruptions since the interest and the conditions will be changing on both sides (Abid \& Ayesha, 2015).

Opportunities. Researcher asserts that despite technical, socio-cultural, political, and security challenges (Masood, 2016), however, in case if the CPEC project bears its fruits successfully in accomplishing its objectives, it will definitely generate several unprecedented opportunities for Pakistan and China (Amna, 2016). For example, it will be an ultimate opportunity for Pakistan and China to generate extra business from the Middle East, Central Asian Republics, and countries in the Middle East, in turn this could boost the economic conditions more successfully which are the pre-requisite for the economic growth and development (Abid \& Ayesha, 2015).

Furthermore, rendering to the route of CPEC that has been designed and planned to also pass through the Punjab province in Pakistan (Aktram, 2016), therefore, it will also generate several employment opportunities for people of the industrially advanced province of the country, which will surely improve the quality of living standards (Salim, 2017). It is believed that CPEC textured as a co-development schema, covering a wide range of strategic investment opportunities that were wished-for to China by Islamabad. Conversely, it transpired at a time when the world's premier “Tsinghai-Tibet railway” became operational.

Threats. Where CPEC is offering ample opportunities for trade and business different regions of Pakistan and strength to its economy, however, it is expected that this gigantic project could face voluminous threats especially that are concerned to security (Aktram, 2016). The CPEC project commencement which has been designed for the corridor may have faced threats from the growing militancy in the regions in general and the Baluchistan province of the Pakistan in particular which is the hub of all of the activities of CPEC wherefrom this his corridor originates, i.e., the Gwadar seaport (Masood, 2016).

Pakistan as well as China will require joint efforts and strategies to quash the militant groups and anti CPEC elements on their borders (Amna, 2016). Both countries may need collaboration, cooperation, and sharing of intelligence and to discontinue the logistics to these anti CPEC groups in order to prevent them from such threats and ensure the safe route besides the threat to their citizens, engineers, and workers (Aktram, 2016). Besides the 
militancy threats, other threats may also include the ethno-political violence in the biggest city of Karachi, inter alia the Taliban militancy in the Khyber Pakhtunkhwa and tribal areas (Aktram, 2016; Haider, 2015). Further, the increasing religious radicalism and extremists, intolerance, and polarization besides the domestic insurgence in Baluchistan could also become possible threats, therefore, it is imperative to nip the evil in the bud before it could become a non-controllable monster to jeopardize the whole plan and efforts (Sial, 2014).

\section{Methodology}

The researcher reviewed the possible available secondary sources on the CPEC. The study is qualitative in its nature, therefore, a computer based software program ATLAS.ti was used to analyze the qualitative data. Major concepts, variables, and sentences from the existing literature were extracted and entered into ATLAS.ti, coding, extraction of quotes, and memos creation were done.

Researchers in the field of qualitative studies have been using different methods, for example, examining, categorizing, tabulating, and recombining for data analysis. Since the study in hand was qualitative in its essence, therefore, the researcher has employed multiple techniques like, discourse by Max (1990), hermeneutics by James (1992), and heuristic by Moustakas (1990) besides content analyses of the data to draw inferences and conclusions.

\section{Schematic Model of the Theoretical Framework}

The schematic model of the theoretical framework elaborates the association and impact between and on the dependent, independent, and mediating variables of the study (see Figure 8).

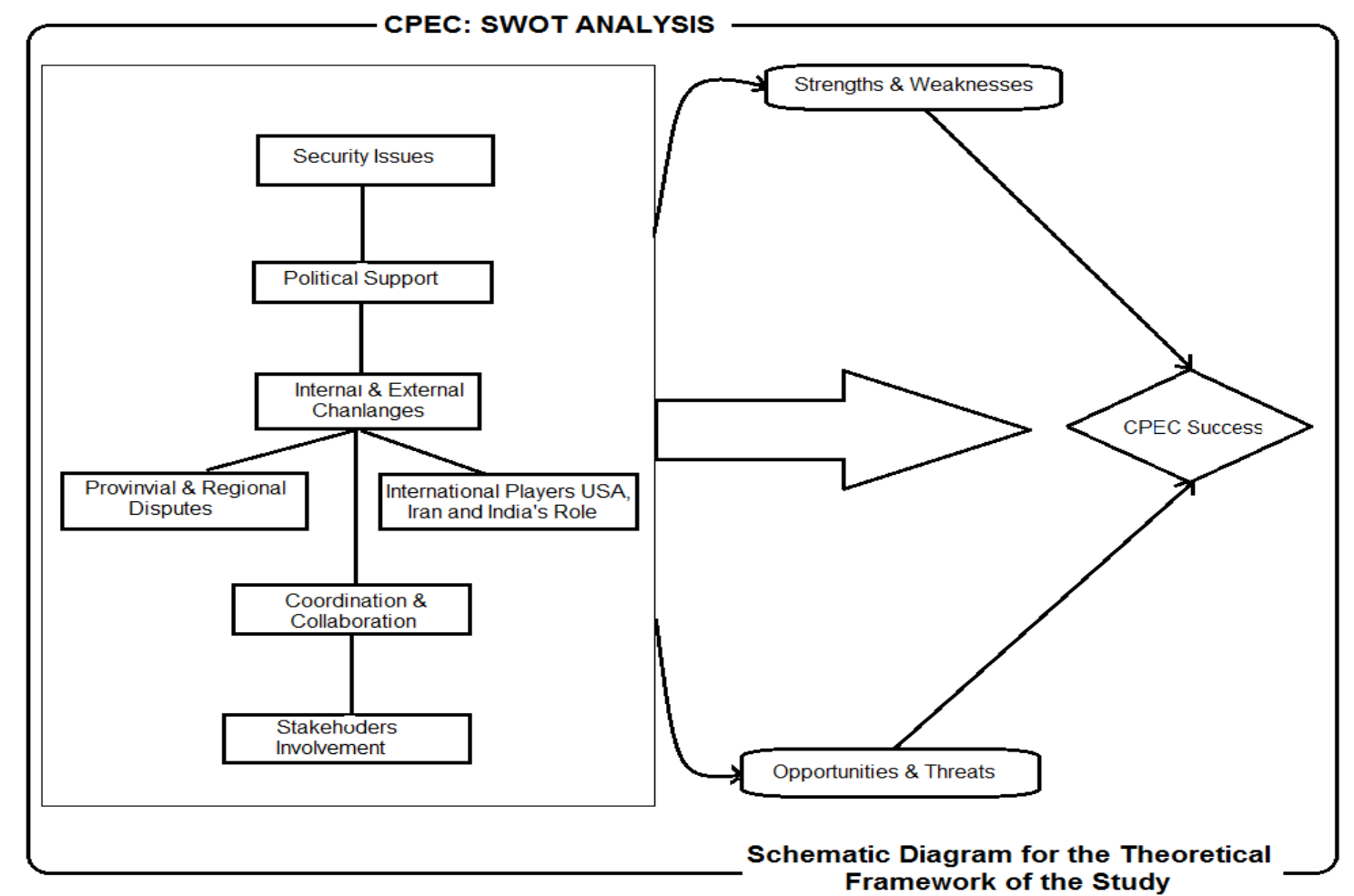

Figure 8. The schematic model of the theoretical framework. 


\section{Discussion and Analysis}

The challenges related to the development of CPEC need to be identified appropriately by both countries, however, as the route and the projects will be mainly spreading over in Pakistan, therefore, it is the responsibility of the government of Pakistan to address them well in time before its final implementation. Though the security concerns of the Chinese have been resolved by setting up a new Special Security Division (SSD).

Likewise, issues related to the CPEC routes and the controversies and tensions among the several political parties and leaders related to CPEC project are required to be kept aside before completion on top priority. Despite efforts and planning by both the partner countries, the CPEC is yet facing many internal as well external challenges.

The biggest issue is the opposition from the neighboring countries like India, Iran, and the UAE (United Arab Emirates) in the Middle East because of threat to their economies (Dawn News, 2016; Barber, 2014). It is not acceptable to Dubai as it will end their supremacy, likewise, India has serious apprehension as it will give strategic and economic edge to its rival Pakistan that is why to contain this project India as an alternate investing on the development of Chabahar seaport of Iran (Haider \& Mahnoor, 2016; Abbas, 2016). Furthermore, USA also would not like the expansion and strength in China business and trade (Amna, 2016). According to Bruce Riedel and Pavneet Singh (2010), the changing geopolitical scenario and the interminably closer Indo-US alliance, and the mounting Sino-US enmity offer India and other cynics with a fresh tactical inspiration to destabilize both the Pakistan and its dream of CPEC (Khan, 2016; Ahmed, 2015). Though recently Pakistan has formed a committed force to ensure the security of the CPEC project (Haider, 2015), this force needs to be further amplified. Hitherto, fending off the foreign mischief through defensive and defensive-offensive mechanisms needs to be given further priority (S. D. Ali, 2017).

The irritation in China has begun and it is growing increasingly because of the delays in the project and issues in mobilizing the funds from Pakistan besides the concerns of the growing unrest in Baluchistan which is one of Pakistan's poorest and most troubled provinces.

The most important issue faced by China and Pakistan is the security of the route. There are various violent factions and groups in Pakistan that are being supported by some of the countries especially some of the religious extremists and the Baloch separatists who are fighting against the state and exploding the infrastructure and installations through their miscreant acts, as the armed insurgency in Baluchistan is considered detrimental and could also derail the whole scheme, for example, in the month of August, a suicide bomb explosion in Quetta the provincial capital took lives of the 70 people (Haider, 2015).

Though Pakistan is making efforts to ensure the peace and security by controlling the law and order for which Pakistan's military has trained a 30,000-strong security force to safeguard the infrastructure and the Chinese engineers, however, it is generally perceived that these kinds of attacks are the attempts to disrupt the massive corridor (Awan, 2016).

Another issue that is also an apple of distort is the social and economic gains of the corridor among the different regions, provinces, and the ethnic communities in Pakistan. Within Pakistan, CPEC has been riddled by suspicion, conspiracy, and bitterness. There are ongoing disagreements over the exact route, the mounting debt, and whether Punjab—-the most affluent province—will reap all the benefits (Clover \& Hornby, 2015). 
The three provinces Sindh, Baluchistan, and the Khyber Pakhtunkhwa feel deprived with regard to their share in the development of infrastructure and business centers. The leadership in these provinces blames the government for neglecting their due rights, share and prioritizing the already developed Punjab.

One of the challenges being reason of debate and disharmony is related to the social and economic gains of the corridor that is why different regions, provinces, and the ethnic communities in Pakistan are showing their apprehensions. Within Pakistan, CPEC has been riddled by suspicion, conspiracy, and bitterness. There are ongoing disagreements over the exact route, the mounting debt, and whether Punjab—the most affluent province - will reap all the benefits. The three provinces Sindh, Baluchistan, and the Khyber Pakhtunkhwa feel deprived regarding their share in the development of infrastructure and business centers. The leadership in these provinces blames the government for neglecting their due rights, share and prioritizing the already developed Punjab.

The review of the existing context of the CPEC unveils the controversies and concerns shown and raised by different stakeholders in Pakistan, and the major could be listed as:

(1) The eastern route benefits the Punjab and Sindh, whereas it bypasses major portion of Baluchistan and Khyber Pakhtunkhwa. While the people holding this opinion assert that western route is an original route, conceived in 2006, and is the shortest;

(2) The second issue is the transparency, according to a quarter of politicians and economists, CPEC is not transparent and kept under wraps;

(3) The three-route theory is a cover story to hide change of route and the eastern route is six-lane motorway compared to the western route, i.e., 1-2 lane roads, likewise, they further argue that the eastern route is unsafe being close to Indian border;

(4) The special economic zones are inequitably distributed;

(5) The government of Punjab Orange Line Train project in Lahore is from CPEC allocations and this is injustice on part of government with small provinces which are already economically weak in Punjab.

As for as the government's stance is concerned with regard to these controversies, government claims that: Some of the anti CPEC elements backed by some foreign agencies are trying to make the project controversial and disputed by widening the gulf through ill designed propaganda (Ahmed, 2015), their thoughts are mostly based on either misperception or planned to sabotage it, and no original route in existence before 2013. The CPEC project director Maj Gen Zahir Shah has stated that no document is in existence that is showing any original route; hence the concern regarding changing of original route does not arise, whereas, work on three routes is progressing simultaneously and the western route will be developed as motorway by extending Kashgar-Karakorum highway.

Both governments of Pakistan and China desired to first complete eastern route due to factors of security, better infrastructure, and early completion, likewise, the western route will be a long term project since it is uninhabited, insecure, and time-consuming (Mahajan, 2015).

The government further says that the provincial capitals will be the nodes of CPEC, and development of backward provinces and regions is high priority of government and CPEC as a 15-year project has short/mid/long term projects. They rebutted the claim of some quarters and assured them that Orange Line project is not funded out of CPEC rather it is the Punjab project funded by the government of Punjab itself, hence no funds will be transferred from CPEC allocations for Orange Line project, and however, China will gift additional funds to complete this project in two years. 
Similarly, the proposed 16 industrial zones have not been finalized (Awan, 2016). The concentration of power projects is more in Khyber Pakhtunkhwa that is followed by Sindh, Punjab, and Baluchistan respectively.

The development projects like CPEC are also driving enormous environmental burdens on Pakistan's meager resources and it is evident from the focus of the government of Pakistan on the dirty coal power in the context of a country that is already highly at risk to climate change confronting protests in the streets and tins the courts across the country (Awan, 2016; Khetran, 2014).

Given the strategic importance of the project and its challenges, one more prominent issue is the lack of coordination within Pakistan and also with Chinese the entities, which according to the business experts necessitate the establishment of an independent "CPEC Authority" that could serve as a "one-stop-shop" in order to resolve and address all issues impeding the success of CPEC (Mahajan, 2015).

Although the government of Pakistan is trying best to address the internal threats and problems of extremist violence and terrorism, yet, it is equally important to counter the support of the India and Afghanistan intelligence agencies, and they are extending to TTP terrorists and Baloch insurgents, especially in the high time of bad relations between Indian and Pakistan with regard to the Modi's reference to Baluchistan and Gilgit-Baltistan.

\section{Conclusions}

To guarantee acceptable spin-off benefits of CPEC to the economy of Pakistan, government should enlarge the scope financial and policy support to CPEC project to cover various sectors of the economy along with the energy and transport.

The goals and benefits of the CPEC could only be fruitful if a more comprehensive and broader role and participation of the private sector in China and Pakistan inter alia the SMEs (Small and Medium Enterprises) are reasonably considered. The Pakistani SMEs and entrepreneurs need to be encouraged to communicate and interact with their Chinese counterparts through sponsorship and arrangement of joint visits to develop a mechanism for regular sharing of business needs, requirements and to discuss the mutual opportunities.

With the CPEC initiation, both China and Pakistan should realize the new veracities and concerns of the global and regional players of the politics by developing more systematic, updated interaction with all players keeping in view their needs and interests for the socio-economic, industrial, energy, and trade uplift.

The Pakistani leadership has rightly described the CPEC as a game changer for the Pakistan as well as for the whole region, yet the fruits of the CPEC will take time to be materialized in the coming 10 to 15 years, this demands the consistent and continued determination and support from Pakistan and Chinese governments (Ali, 2016).

Most of the human resources, the professionals, and laborers will be working on the Pakistani soil to build the essential infrastructure like engineers, technicians, and labors, therefore their security and safety must be ensured. Since the commencement of the CPEC, the role of enemy intelligence agencies in the areas where CPEC roads for transportation are passing through must be protected and safeguarded, there bringing peace and normalcy to develop the confidence of the investors and business community, a strong and capable rapid response security system should be in placed on priority basis to prevent any sabotage detected and handled. The erection of Special Security Division by Pakistan army in April 2015 that consists of nine army battalions and six wings of paramilitary forces (Rangers and Frontier Corps) with 10,000 personnel under the command of an officer of the rank of major general shows commitment of Pakistan to address security concerns of the stakeholders. 
The engagement of Pakistan by China will have an opportunity to counter-balance the Indian-US strategic nexus and partnership and the anti-state elements conflicting and opposing the establishment and development of the corridor as they are misguiding the local people in Baluchistan, Khyber Pakhtunkhwa, and Gilgit-Baltistan by creating disharmony and the law and order. These external forces are trying to make it disputed and thus, the extremist/ethnic elements could also be exploited to sabotage the CPEC.

Likewise, on part of China, the East Turkistan Islamic Movement (ETIM) in Xinjiang has also been exploited to damage the CPEC and create law and order problems in Chinese areas.

To counter these irritated elements and to foil their unseen reprehensible schemes, the government of Pakistan needs to design and execute a multi-dimensional approach covering both soft as well as the hard power, which necessitates the establishment of Pakistan-China joint counter terrorism mechanism.

It is expected the CPEC will transform Pakistan future as well as its geographic location into an asset. To ensure the high level of performance and quality in the CPEC project, a handy and systematic audit, monitoring, and evaluation will be required to prevent the chances of the corruption, in this direction the establishment of the Prime Minister's Delivery Unit (PMDU) in April 2015 for monitoring the execution of various CPEC projects is a healthy and positive step.

\section{Recommendations}

With this context, based on the critical examination and analysis of the available sources of the facts and figures, it is suggested that several steps can be taken both by Pakistan and China to ensure the realization of the CPEC. As for as the role of Pakistan is concerned, as the major player and host of the CPEC, Pakistan should make certain:

(1) Fair allocation and sharing of economic benefits of the CPEC project throughout the country, especially the provinces and regions. It is imperative to counter the attempts made by the external forces for creating internal disharmony and cord in the country;

(2) Pakistan should overcome its turbulences in economic growth and development in bringing more consistency in its economic plans and policies;

(3) Transparency in the core of success in today's dynamic world, therefore, to avoid the negatives and dangers associated with charges of crony capitalism, transparency in decision-making must be ensured;

(4) To minimize the dissatisfactions and conflicts among the different stakeholders, a mechanism of the speedy and fair dispute resolution should be put in place, to prevent and avoid time-consuming litigation processes;

(5) Capital market is the driven features of modern economies, and to provide adequate local financing in the projects, it should be reasonably encouraged and expanded;

(6) The qualified professionals are the core for any success, thus, availability of the qualified professionals for implementation of the thorough large-scale programs may be initiated on priority basis for the vocational training and skills;

(7) A joint group by Pakistan and China of experts from different fields including international and strategic experts, military and security specialists, politically matured parliamentarians, and seasoned education, economic and business experts may be formed to regularly scan and monitor internal and external threats and to plan and devise timely strategies, to share, cooperate, coordinate and not only to overcome the threats but also to avail the possible opportunities. 


\section{References}

Abbas, S. S. (2016). Iran wants to be part of CPEC, says Rouhani. Retrieved from https://www.dawn.com/news/1285404

Abid, M., \& Ayesha, A. (2015). CPEC: Challenges and opportunities for Pakistan. Pakistan Vision, 16(2), 142-169.

Ahmar, M. (2015). Strategic meaning of the China-Pakistan economic corridor. Retrieved from http://issi.org.pk/wp-content/uploads/2015/12/Moonis-Ahmar_3435_SS_41_20142015.pdf

Ahmed, M. (2015). Sino Pakistan relations and the challenges of post-cold war era. Contemporary Chinese Political Economy and Strategic Relations: An International Journal, 1(1), 37-50.

Akhter, S. (2016). FDI up 15pc on CPEC inflows in July-March. The News, April 19, 2016.

Aktram, M. (2016). Opportunity and challenge. Retrieved July 18, 2017, from https://www.dawn.com/news/1281862

Ali, A. (2016). China Pakistan economic corridor: Prospects and challenges for regional integration. Arts and Social Sciences Journal, 7(204), 1-5.

Ali, S. D. (2017). Impact of CPEC on regional international relations. Retrieved March 14, 2017, from http://www.ia-forum.org/Content/ViewInternalDocument.cfm?ContentID=8596

Amna, E. R. (2016). Completion of CPEC: Impact on Pakistan's strategic position and economy. Retrieved March 16, 2017, from http://www.ipripak.org/completion-of-cpec-impact-on-pakistans-strategic-position-and-economy/

Awan, S. (2016). CPEC to benefit all Pakistanis. Retrieved March 16, 2017, from http://pakobserver.net/cpec-to-benefit-all-pakistanis/

Aymen, I. (2016). Importance of CPEC. Retrieved August 11, 2017, from http://pakobserver.net/importance-of-cpec/

Barber, C. E. (2014). The Pakistan-China corridor: A new project will give Pakistan the tools of globalization. Will it use them?. Retrieved from http://thediplomat.com/2014/02/the-pakistan-china-corridor/

Clover, C., \& Hornby, L. (2015). China's great game: Road to a new empire. Retrieved from http://www.ft.com/cms/s/2/6e098274-587a-11e5-a28b-50226830d644.html\#axzz43EfT1yuV

Dawn News. (2016). Iran, India, Afghanistan sign transit accord on Chabahar port. Retrieved from http://www.dawn.com/news/1260176

Haider, M. (2015). Army's special security division to protect Chinese workers in Pakistan. Retrieved from http://www.dawn.com/news/1177322

Haider, M., \& Mahnoor, B. (2016). Chabahar not a rival to Gwadar, Iranian envoy tells Pakistan. Retrieved from https://www.dawn.com/news/1261006

Hussain, J. (2016). China Pakistan economic corridor. Defense Journal, 19(6), 13-21.

Irshad, M. S., Qi, X., \& Arshad, H. (2015). One belt and one road: Does China-Pakistan economic corridor benefit for Pakistan's economy. Journal of Economics and Sustainable Development, 6(24), 203.

James, P. G. (1992). Discourse analysis. In M. LeCompte, et al. (Eds.), The handbook of qualitative research in education (chapter 6). San Diego, Academic Press, USA.

Khan, S. (2016). RAW, NDS patronizing terror groups in Afghanistan, National Security Adviser tells U.S. envoy. Retrieved from https://www.dawn.com/news/1292399

Khetran, M. S. (2014). The potential and prospects of Gwadar port. Institute of Strategic Studies Islamabad (ISSI) Journal, 34/35(4/1), 73.

Mahajan, A. S. (2015). Worrying signals: China's growing investments in Pakistan could prove to be a headache for India. Retrieved

http://www.businesstoday.in/magazine/focus/china-investments-in-pakistanrising-headache-for-india/story/218868.html

Masood, T. (2016). CPEC challenge and opportunity. Retrieved August 19, 2017, from https://tribune.com.pk/story/1250681/cpec-challenge-opportunity

Max, V. M. (1990). Hermeneutical analysis: Researching lived experience. State University of New York Press. USA.

Moustakas, C. (1990). Heuristic research. Academic Press, Newbury Park. USA.

Nawaz Sharif. (2017). The CPEC will change the destiny of the Nation: Address to Cabinet Meeting. Daily Jang Lahore, May 13, 2017.

Riedel, B., \& Singh, P. (2010). U.S.-China relations: Seeking strategic convergence in Pakistan. Retrieved from https://www.brookings.edu/wp-content/uploads/2016/06/0112_US_China_Relations_Riedel.pdf

Ritzinger, L. (2015). The China-Pakistan economic corridor-Regional dynamics and China's geopolitical ambitions. Retrieved from http://nbr.org/research/activity.aspx?id=589 
Rizvi, H. A. (2014-2015). The China-Pakistan economic corridor: Regional cooperation and socio-economic development. Institute of Strategic Studies Islamabad (ISSI) Journal, 34/35(4/1), 10.

Salim. (2017). The Potential Socio-Economic Impact of China Pakistan Economic Corridor. Asian Policy Development Review, 5(4), 191-198.

Shah, S. M. A. (2017). Chabahar vs. Gwadar. Retrieved from https://www.dawn.com/news/1181003

Sial, S. (2014). The China-Pakistan economic corridor: An assessment of potential threats and constraints. Conflict and Peace Studies, 6(2), 11-40.

Simrit, K. (2016). Gwadar port operationalization: India, US need to redraw maritime strategy. Retrieved June 10, 2017, from http://www.indiandefencereview.com/spotlights/gwadar-port-operationalisation-india-us-need-to-redraw-maritime-strategy/

Trading Economies. (2016). Pakistan economic indicators. Retrieved from https://tradingeconomics.com/pakistan/indicators

Wang, Y. (2016). Offensive for Defensive: The Belt and Road Initiative and China's new grand strategy. The Pacific Review, 29(3), 455-463. 